\title{
THE MUSEUM'S MISSION IN CONTEMPORARY SOCIAL AND CULTURAL REALITIES
}

\section{ELENA MASTENITSA - LYUDMILA SHLYAKHTINA https://doi.org/10.5817/MuB2017-2-2}

\section{ABSTRACT/ABSTRAKT:}

The rapid and irreversible changes that occur in the contemporary world dictate the need to find the ways and methods to renovate traditional cultural institutions including the Museum. The authors of this article focus on the issues of the Museum's mission in the context of global challenges and socio-cultural transformations. As noted by the authors, two current trends coexist and complement the Museum vision: social inclusion and retaining the Museum status as a place alternative to the mundane everyday life, excluding it from the familiar environment into a paradoxical, but at the same time real space, where one can meet the past, which bears the image of a bygone time with its characteristic features. In conditions of an open information society, the ability of the Museum to preserve tangible and intangible heritage accumulated in its collections and, moreover, to produce innovative cultural products, events and meanings, moves to the forefront. The Museum needs an image of an open, vibrant structure, targeted equally at both the urban elite, and the mainstream audience including people with disabilities. Cultural and social formations become priority components of the Museum's mission.

\section{Poslání muzea v současné společenské a kulturní realitě}

Rychlé a nezvratné změny v dnešním světě vyvolávají potřebu najít způsob a metody, jak inovovat tradiční kulturní instituce včetně muzeí. Autorky článku se zaměřují na otázku poslání muzea $\mathrm{v}$ kontextu globálních změn a společenskokulturní transformace. Podle nich se v současné době v oblasti vize pro muzea objevují dva souběžné trendy, které se navzájem doplňují: sociální inkluze a potřeba zachovat status muzea jako místa, které představuje alternativu každodenní reality, což jej přesunuje ze známého prostředí do paradoxního, ale zároveň reálného prostoru, kde se lze setkat s minulostí, které nese otisky dávných dob s jejich typickými rysy. $\mathrm{V}$ podmínkách otevřené informační společnosti vystupuje do popředí schopnost muzeí uchovat hmotné i nehmotné dědictví nashromážděné ve sbírkách, a navíc vytvářet inovativní kulturní produkty, události a významy. Muzeum by mělo být otevřenou, živou strukturou zaměřenou jak na kulturní elity, tak na běžné návštěvníky včetně zdravotně postižených. Utváření kultury a společnosti se stává hlavní prioritou v poslání muzea.

\section{KEYWORDS/KLÍČOVÁ SLOVA:}

museum - museology - cultural heritage - globalization - mission social inclusion - edutainment volunteer movement muzeum - muzeologie - kulturní dědictví - globalizace - poslání sociální inkluze - edutainment dobrovolnické hnutí
The Museum's mission is interpreted by modern researchers as "an intended purpose defined as generating culture, both present and future, based on preservation and maintenance of the most valued parts of all types of heritage, as [...] a policy statement, which outlines the main purpose of the Museum, its role and public nature". ${ }^{1}$ According to Tomislav Šola, "the Museum's mission, as before, is the commitment to the common well-being and unwavering dedication to the social idea based on humanistic ethics". ${ }^{2}$

\section{The Museum's mission: pro et contra}

The views on the Museum's mission are conditionally divided into two camps: representations of museum conservatives and those of museum reformers.

Conservatives assert a certain "sacredness of the Museum's mission, its rootedness in the sphere of top values". ${ }^{3}$ Under the sacral approach, the most important area of the Museum activities is that one where an object becomes a monument; therefore, preservation refers to the primary objectives of the Museum. From this point of view, the cultural value of an object gains special importance and working with visitors is reduced to familiarizing them with supreme

\footnotetext{
1 Dictionary of current museum terms. Museum 2009, no. 5, p. 55.

2 ŠOLA, Tomislav. Eternity does not live here anymore. A glossary of museum sins. Tula, 2013, p. 106.

3 LEBEDEV, Alexey V. Museums of the future: information management. Moscow: Progress-Tradition, 2001, p. 64.
} 
values stored in museums.

According to conservatives, the Museum collections should be kept under the state ownership and the state is bound to provide full support to museums.

Reformers came into the spotlight in the 1990s and they are critics of conservatives. Their views are closely intertwined with the trends in the Museum development in light of the globalization impact. They are convinced that the state patronage over museums should be gone; hence, the preservation of heritage should be based on the principle of its active use. In the view of modernizers, "partnership-based, project-oriented and network technologies will become the most efficient method of fundraising and formulating the long-term development strategies for the Museum's activities". ${ }^{4}$ The general idea of this approach is to refocus the Museum activities from the internal (collection and research) to external (individual and society) scope. Thus, the priority of communication over the storage function is stated and the educational model is gradually replaced by information and communication model.

According to A. M. Kulemzin, "the primary mission of the Museum is not just performing specific functions but is more extensive and includes, inter alia, shaping the mindset of the wide population". ${ }^{5}$ The same idea is shared by S. I. Sotnikova who considers that "the Museum is an instrument for shaping the basics of a person's mindset". ${ }^{6}$ T. Y. Yureneva argues that the contemporary Museum "should play the leading role in human perception of his

\footnotetext{
4 Ibid, p. 65.

5 KULEMZIN, Anatoly M. Ideological aspects of mseology. Bulletin of Kemerovo State University of Culture and Arts, 2012, no. 18, p. 31. 6 SOTNIKOVA, Svetlana I. Natural history museum: from scientific factology to formation the bases of ecological culture (historical journey) In Abstracts of the scientific conference, November 25-26, 1997. Moscow, 1997, pp. 20-22.
}

natural and social environment in all its manifestations". ${ }^{7}$

Museologists T. G. Shumnaya and A. S. Balakirev are convinced that the contemporary Museum "attempts to leap into the sphere of the actual culture production". 8 Its activities build upon the specific cultural needs of visitors, which, in turn, account for the religious and ethnic identity, socio-professional characteristics, age, etc. "The Museum is a unique social formation intended to serve as a place of meetings and productive intercultural interaction, information and value exchange between different communities, ethnic groups, generations, professional, age-specific, territorial and other subcultures."

\section{Challenges of the global world and global culture}

Transformation of the Museum's mission is determined by the challenges of modern times. Among them is globalization, a complex and multi-component process, which is based on the information revolution. It has a decisive influence on all spheres of social life and human activity politics, economics, culture, language, education, spiritual and moral development, interethnic and inter-confessional relations. Globalization represents a powerful factor of spatiotemporal transformation in modern human existence. Geographical and state borders become more transparent; transcontinental links and cross-cultural communication are intensified. In other words,

\footnotetext{
7 YURENEVA, Tamara Y. The museum in world culture: monograph. Moscow: Russian word, 2003, p. 464.

8 SHUMNAYA, T. G. (ed.). Museums of historical profile. Cultural mission. Moscow, 2008, p. 62.

9 MORKOVKIN, Y. V. Development strategy for the cultural institution. Market models of economic activity, case study of Ryazan historical and architectural museum-reserve. Handbook for head staff of the cultural institution, 2004, no. 3, p. 33.
}

the human life is increasingly influenced by actions and events that occur far enough from its immediate social environment. Transition from traditional society to technogenic computerized virtual civilization is catalyzed by the globalization process and causes axiological transformation.

Today, understanding the mission and overarching goal of the Museum is actualized by the context of globalization, as well as the establishing information society, which is characterized by segregation and isolation, loneliness in "the global village", communications via personal but non-personalized communication channels (email, mobile phones, etc). People have lost their roots and are left with scraps of cultural contacts and fragments of identity. Modern man is focused on the consumption of spiritual "fast food" and creates an "intellectual GMO".

A new paradigm of transmodernism came as a response to these processes. It is determined by the emerging human need of communion, increased desire for impressions, feelings and experience, to fill the emotional void that was created by the postmodern world. According to R. Jonsen, transmodern reality is full of stories that make a natural source for the development of museums. In turn, the history relies on reality and human experience that can be proposed to other people. The scientist suggests that in the society of the future, information will be transferred with the help of pictures, stories, myths and legends, instead of letters and digits adopted in the information society. Pictures and images will become a new common language. A sense of permanence and continuity will be in the top requested and people will "buy emotions", stories and new experience that should be of high 
quality, integrity and stimulating creativity. It is the creativity that should make the basis of intellectual and emotional visitor's contacts with the Museum. ${ }^{10}$ Being a space that links the timeless and the individual, the past and the present, the Museum unites them into an integral whole and makes the past real.

The process of globalization that levels cultural differences, erases national features and consequently leads to the erosion of identity is opposed by "glocalization", which is understood as the adaptation of elements of modern culture to the local conditions of different countries and local traditions of different peoples. The heterogeneity of regional forms of human activity becomes the norm. This can stand as a basis both to keep and to revive the material and spiritual culture of a nation or an ethnic group, to assimilate and develop local cultural traditions, as well as to preserve local civilizations. The Museum can and should become the focal point of these trends.

In our view, "glocalization" in the Museum development during recent decades was vividly demonstrated by creating single-subject, specialized museums dedicated to a single topic, subject, or area of human activity, a natural or social phenomenon. This trend is observed both in metropolia and in small towns or rural areas. In big cities, such museums can be viewed as a way to resist unification and the power of stereotypes brought by globalization. This confrontation reflects an intention to preserve the Museum as a space of genuine items bearing the memory of the past, a desire to make museums

10 AHMAS, Christina. Museum in the

transmodern era. In Museology in the 21st century: problems of learning and teaching. Materials of the International scientific conference, Saint Petersburg, May 14-16, 2008. Saint Petersburg, 2009, p. 131. understandable and rateable to any person, "homely", in a sense.

In small towns and settlements, creation of new museums dedicated to the events that occurred on the same territory, or a person that left a mark in the history of the region, emphasizes their cultural significance and uniqueness, which determines the mission of regional or local museum. It should be noted that the idea of creating such museums belongs to ambitious people who often consider the Museum as a commercial project, as well. This resulted in a fairly large group of private museums and their intensive growth is registered as a global trend. At the moment, the exact number of private museums in Russia can not be identified. Their number increases daily and their geography covers the whole country, as evidenced by just a few examples: the Furniture Museum in Moscow, V. I. Deryabkin's Museum of Gramophones and Phonographs in Saint-Petersburg; "Nevyansk Icon" Museum in Ekaterinburg; "Music and Time" Museum in Yaroslavl, etc. Similar projects exist in other cities, too. Thus, the Marzipan Museum in Kaliningrad is dedicated to the exquisite confectionery produced traditionally on this land, its history, geography, ingredients and existence in the culture. The Museum founders hope to bring the culinary brand back to its historic place of origin by combining the past and the present in the culture of this region.

Museums of culinary products marzipan, marshmallow, cakes, butter, cheese, vodka - are always popular with the public. Probably, this is because a museum object takes a special status - it becomes really accessible to every visitor. It can be seen in the exhibition or be bought and taken away. Moreover, every visitor is an expert who evaluates the Museum object to his/her taste.

New economic conditions in the post-Soviet territory gave rise to the "brand museums". Their characteristic feature is that the Museum's concept is based on a brand, an image, or an idea supposed to attract visitors. For example, Georgia is known as the cradle of wine and winemaking culture. It is therefore not surprising that there exists a Museum of Wine and Winemaking at the private winery in Velistsikhe village surrounded by vineyards. Here, the history and brewing technology is visually demonstrated in a special building, and a winery tasting lounge and a shop are also present.

Such museums sometimes appear in settlements that do not feature the cultural and historical heritage great enough to attract tourists and thus play the role of artificial "catalyst" of interest to the place; sometimes they emerge as a complement to the attractive historical and cultural environment. The major objective of these establishments is to transform the Museum programs into a tradeable Museum product, along with the development of concepts, such as "trademark", "brand", "house style", "marketing chart", and "promotion strategy".

Another example of the brand museum is Vologda Butter Museum located on the territory of the Architectural and Ethnographic Museum Semyonkovo, the Vologda oblast. It is placed in a peasant home and visitors are familiarized with the origins of butter-making, which made a brand of the Vologda region. In this Museum, visitors gain knowledge through the encounter with the historical epoch and participation in traditional ceremonies. The reconstructed peasant farmyard gives an idea of 
farming methods in the northern village.

The emergence of these museums confirms the notion of increasing demand for individuality, originality, project creativity and non-standard thinking in the era of globalization; attention to the unique and authentic is not declined. This expands the view on the essence and frontiers of the heritage and is particularly relevant in view of the anthropogenic, technogenic and military threats of irreversible loss of the heritage objects or its entire layers.

\section{Cultural heritage and the Museum in the postmodern situation}

The global trend in the 20th century was the scientific comprehension of the heritage, which made possible classifying the monuments into groups of monuments and memorial sites. In the second half of the 20th century, the range of heritage objects under the aegis of UNESCO expands gradually and a diverse, differentscale material evidence of human activities and the environment is included. Today, the concept of heritage refers to artifacts and natural objects, without limitations in time and space, regardless of whether they were intentionally collected and preserved for the future generations or inherited from the antecedents. At the threshold of the 21st century, the concept of preserving heritage became a social imperative; efforts were made towards realizing the fact that the heritage belongs to the society and, by accepting it, the society is committed to preserve it.

We can observe the revision of attitudes to the natural and cultural heritage, which is more visibly transformed into the basic value of the modern civilization. It is the heritage that plays a crucial role in the sustainable social and cultural development of the mankind. By the end of the 20th century, in addition to collecting, storing, researching, and exhibiting Space and Time, museums started dealing with Action. The idea of "new museology", offering innovative museumification purposes, changed decisively the earlier concept of the Museum complexes, which started rapid integration into the environment, "conquering" new territories and covering more places in the open space (architectural ensembles, natural complexes, mines, placers, quarries, industrial facilities, etc.). The emergence and development of ecomuseums presents to visitors the unity of geographical and cultural characteristics of the entire region. The ecomuseum became a universal type of the Museum and developed intensively in different countries. ${ }^{11}$

Changing attitudes to the heritage and the Museum explains the pathos of debates in the international museological community. Analysis of the sociocultural conditions suggests that "a change in the 'Museum paradigm' takes place today - transformations of the Museum's system are so significant and irreversible that we should speak of the birth of a new understanding of the Museum, formation of a fundamentally new concept of the evocation of museality, rather than of certain changes in the Museum". ${ }^{12}$ This aspect is closely studied by O. S. Sapanzha, who indicates the transformation of the cultural form of "the Museum", as such. ${ }^{13}$

\footnotetext{
11 KUKLINOVA, Irina A. Ecomuseums and the concept of regional cultural identity (Case study of France). In Global cultural space. Proceedings of the International scientific forum, April 12-16, 2005. Saint Petersburg: Centre for cultural studies, 2005, pp. 346-348.

12 SAPANZHA, Olga S. The theory of the museum and museality: historiographical overview and historical typology. Monograph. Saint Petersburg: NEE "Express" risograph, 2011, p. 4. 13 Ibid.
}

In 2001, the International Council of Museums (ICOM) adopted a decision on granting the status of the Museum to a wider range of institutions. These include:

- natural, archaeological and ethnographic monuments and sites and historical monuments and sites of a museum nature that acquire, conserve and communicate material evidence of people and their environment;

- institutions holding collections of and displaying live specimens of plants and animals, such as botanical and zoological gardens, aquaria and vivaria;

- science centres and planetaria;

- non-profit art galleries; conservation institutes and exhibition galleries permanently maintained by libraries and archive centers;

- nature reserves;

- international/national/regional/ local museum organizations, ministries or departments or public agencies responsible for museums as per the definition given under this article;

- non-profit institutions or organizations undertaking conservation, research, education, training, documentation and other activities relating to museums and museology;

- cultural centers and other entities that facilitate the preservation, continuation and management of tangible or intangible heritage resources (living heritage and digital creative activity);

- such other institutions as the Executive Council, after seeking the advice of the Advisory Committee, considers as having some or all of the characteristics of a museum, 
or as supporting museums and professional museum personnel through museological research, education or training. ${ }^{14}$

Smearing "the Museum" definition involves the risk of possible loss of the phenomenological significance of this socio-cultural institution. Reflections on the future of the Museum gave birth to the concept of the "post-museum", which is close to the ideas of "neighborhood museums" in the USA and "community museums" in Latin America. ${ }^{15}$ Russian museologists use this term to denote an institution that has reinterpreted itself and is committed to share its authority with the community it serves. ${ }^{16}$

\section{The Museum world in the 21st century: the frontiers and horizons of the development}

Expanding the frontiers of the Museum world led to the introduction into scientific terminology the concept of "museum-type institution", which separates from the classical interpretation of the "Museum" concept. According to M. E. Kaulen, the "level of museality" among the "museum-type institutions" that populate the current Museum world can vary considerably, "from traditional museums implementing non-traditional forms of Museum activities, to institutions that have almost nothing in common with the Museum and have appropriated this name to themselves as a label, a sign of quality, a would-be guarantee of

14 ICOM Russia Charter [online]. [cit. 2017-10-11]. Available from www: < http://www.icom.org.ru/ get.asp?id $>$.

15 LESHCHENKO, Anna. The problem of formation of museological terminology at the international level. Museum, 2009, no. 5, p. 45

16 CHUGUNOVA, Anastasia V. Socio-cultural image of the modern museum: models of

architectural implementation. Saint Petersburg, 2012. 22 p. PhD thesis, Culturology. high spirituality and elitism of this institution". ${ }^{17}$

Foreign museologists take a challenging approach to the management of such institutions. The management recommendations of the European and American experts include the following:

- the museum-type institution should not only demonstrate the exhibit but also provide the relevant explanation;

- visitors are allowed not only to view the exhibit but also to touch it, to see the processes of its restoration or replication and even to take part in these processes;

- the museum-type institutions should provide visitors an opportunity to relax, have fun and a good meal. ${ }^{18}$

In this regard, British museums make an illustrative example. An interesting visitor activity is implemented in the Museum of the Moving Image in London. This is a unique Museum of cinema and television including 50 diverse rooms, which present the first steps of the Hollywood directors, the Chinese shadow theater, and the Soviet propaganda films. In the Department of television and animation, visitors can take part in the movie filming, get all the details of film production, act as a TV presenter, make one's own cartoon and even take a film test for a Hollywood movie. ${ }^{19}$

Institutions that represent a combination of the Museum with another institution, e.g., a school

17 KAULEN, Maria E. Museum or non-museum. Museum, 2010, no. 8, p. 5.

18 KUZMINA, E. I. and V. R. FIRSOV (eds.). Cultural policies in Europe: Selection of strategy and milestones: coll. of materials. Moscow: Liberia publishers, 2002, p. 95-96.

19 London walk. Museum of the moving image [online]. [cit. 2017-10-11]. Available from www: $<$ http://weekinlondon.ru/?p > museum, a pharmacy museum, a theater museum, a library museum, a factory museum, etc., become more common. For instance, there is a private Museum and Theatre of Wine in Kislovodsk, which combines a shop, a museum exhibition and a tasting room, where tasting elite wines is accompanied by a lecture on the history and traditions of winemaking and theatrical sketches. In Elabuga, there is an active Museum-Inn-Theater, in St. Petersburg - Museum-pharmacy, etc. $^{20}$

Another type of the Museum institution is the so-called "economuseum", the term suggested by the Canadian museologist S. Simar. An "economuseum is a museum-type institution, which functions as a combination of the Museum and small workshops focusing on the creative use and perpetuation of traditional skills and craftsmanship. The name 'economuseum ' is to emphasize the economic component of such cooperation. Heritage sites are used as a 'source of inspiration', new items are created upon the traditional technology, and the craft as such is preserved as an object of intangible cultural heritage". ${ }^{21}$ As a rule, these "new items" are sold in shops, which make an integral part of the economuseum, and a demonstration of the product manufacturing, with direct involvement of visitors in this process represents an important attraction for the visitor-buyer.

In our opinion, expanding the range of documented objects does not diminish the role of the Museum in its societal service and in solving social and humanitarian problems. The international professional

20 KAULEN, Maria E. Museum or non-museum. Museum, 2010, no. 8, p. 6 .

21 Dictionary of current museum terms. Museum, 2009, no. 5, p. 64 
community attempted to structure scientific research by formalizing the definition published in the ICOM "Museum Code of Ethics" in 2006: "A museum is a non-profit, permanent institution in the service of society and its development, open to the public, which acquires, conserves, researches, communicates and exhibits, for purposes of study, education and enjoyment, the tangible and intangible heritage of humanity and its environment."22

The contemporary Museum is both a repository and its contents. It has clear objectives and functions, a mission and message, since every Museum, regardless of its size and profile, represents a manifestation of ideas and intentions. The Museum spaces are in constant interaction with those who visit them. They affect people's perception through fulfilling specific objectives and thus create a new reality, where the focus is shifted from the subject to the individual and the society.

Thus, museums act as agents of social inclusion and social responsibility of the culture. This is related to global processes that change the self-perception of the society, its socio-cultural institutions, and the principles of interaction within the society. In the late 1990s, the concept of web 2.0 social networks appeared, where the users act as co-developers and content contributors. It has induced great alterations in the principles of relations between people.

Communication was progressively moved to social networks that allow maintaining contacts with people halfway around the world and are easier and faster to organize the like-minded people. The 2.0 ideology appeared to be consistent with the already existing

22 ICOM Code of ethics for museums. Moscow: ICOM Russia, 2007, p. 16. idea of the participatory democracy that implies a decentralized, collective decision-making in all areas of public life. Thus, the processes described by scientists as shaping a new "culture of participation" take place in many areas of public life. ${ }^{23}$

\section{The Museum in the context of a "culture of participation"}

One of the trends related to the principles of "culture of participation" in museum activities is the development of a volunteer movement. Examples of these activities in many countries are common and quite convincing. The Fitzwilliam Museum at the University of Cambridge invites the volunteers to participate in the description of the Ancient Egypt collection; the ability of the project participants to recognize and identify hieroglyphs is particularly appreciated. An example of a traditional interaction between the Museum and the society is mobilizing volunteers to collect items for the exhibition. An interesting and productive experience is provided by the Memorial and Historical Museum in Volgograd, which addressed the city residents with a request to contribute the authentic objects for the First World War exhibition. This request resulted in filling the exposition content with such unique items as the Mosin rifle bayonet, the regimental money box, and the early XX century Psalter. The most common practice of cooperation with volunteers is their participation in cultural and educational programs and actions. Other examples of active volunteering in Russia are: the annual event "Night at the Museum", "Children's days at St. Petersburg museums", etc. The

23 AGAPOVA, Daria. Culture of participation: millions of dialogues. In SHCHERBAKOV, A. (ed.). Museum as an educational space: game, dialogue, culture of participation. Moscow, 2012, p. 9. recent social practices of museums dictate the need of volunteer work to be focused on people with disabilities. The Metropolitan Museum programs for visitors with dementia and those on the autism spectrum envisage voluntary cooperation. It can be assumed that the volunteers' expectations of their humanistic service are fully implemented through such practices.

\section{The Museum's mission as a theoretical problem of museology}

Current understanding of the Museum's mission is reflected in the ideas of new museology concerned with the inclusion of local community museums as custodians of the intangible cultural heritage. These approaches are closely linked to the theoretical bases and critical museology, which builds upon the recognition of the dialectical interconnection in the society, its social institutions and the surrounding reality. Proponents of this theory draw attention to the subjectivity of knowledge streamed via the Museum instruments and their dependence on economic, political, and cultural context of a particular historical era. Therefore, they are convinced of the need for a multifaceted interpretation of different themes and stories, as well as for the transformation of the Museum exhibition into a discussion platform.

Scientific approaches in critical museology are associated with the development of the theory of Museum communication, which recognizes the possibility of different interpretation of knowledge gained in the Museum. The acceptance of plural truths, different views on the same cultural events and phenomena should be clearly 
demonstrated in the Museum exhibition. However, proponents of the critical museology consider addressing the issues of societal importance to be central in their approaches to the Museum's mission. Thus, O. Navarro believes that the Museum can not only pose questions to the public but also exert certain political and psychological influence on the society. ${ }^{24}$ This thesis is developed by R. Sandell who argues that the Museum is an agent of social inclusion, which ensures involvement of all population groups isolated from the society for some reasons (poverty, ethnicity, unemployment, poor health, etc.), and draws attention to the need of solving this problem at the state level. With view of the great educational and cultural potential available in the Museum, its mission should be implemented as part of its functioning, which is to serve the society and facilitate positive changes at different levels: individual, specific social groups and the whole society. ${ }^{25}$

\section{The Museum as an accessible environment: principles of organization and technology of functioning}

In humanistic discourse, changing the vector of interaction between the Museum and the society implies changing the Museum space, both in a direct and metaphorical sense. Thus, development of social practices of the contemporary Museum involves the use of a wide range of technologies of interaction with the real and potential audience. One of them is the introduction of the universal design principles, which means

24 NAVARRO, Oscar. History and memory in the contemporary museum: a few observations from the point of view of critical museology. Problems of museology, 2010, no. 2, pp. 3-11.

25 SANDELL, Richard. Social inclusion, the museum and the dynamics of sectoral change. Museum and Society, 2003, vol. 1, no. 1, pp. 45-62. creating a comfortable environment for visitors with varying physical and mental needs. Sociocultural practices for arranging the Museum's accessibility should be implemented in close relationship, both physical and attitudinal, which assumes conceptualization of the Museum as a place for practical hermeneutics and the "factory of impressions", encouraging the development of museum pedagogical, mediation and multimedia technologies.

Cognitive accessibility is achieved through introducing edutainment technology into museum pedagogical practice. It should be emphasized that under realities of the contemporary Museum world, this approach helps to overcome the active, and sometimes aggressive, introduction of amusements and entertainment. ${ }^{26}$ The aggressive use of entertainment programs in the Museum activities is explained by some experts as an attempt to cope with the "museum fatigue" problem and the cognitive vanity of museum specialists against uneducated visitors, in addition to commercial motives. The recreational component in the museum educational and mediation practices is not just a relaxation but an activity aimed at expanding the horizons, developing the spiritual, intellectual and emotional capacities of a person. Russian experience in edutainment proves its importance in reading the meanings embedded in the museum objects and expanding the sensual unidimensionality of the Museum. The Knights' tournaments in the Vyborg Museum of local lore (Leningrad oblast), Ethnographic Pan Theater

\footnotetext{
26 "Edutainment" (education + entertainment) is an informal term to denote combination of education and entertainment, introduced in the 1980s. Later, the edutainment technology was included actively in various socio-cultural spheres and became popular in recreation and educational activities of the Museum.
}

in the Russian Ethnographic Museum (St. Petersburg), music and audio accompaniment at expositions, and even the odors ("Scents of Caravaggio", the State Hermitage project) are just few illustrations of such practices. That is why recreation becomes part of the educational process in the Museum, when the education is no longer aimed at awareness raising only but shapes it in cultural and educational objectives of the integrated personal development.

Thus, the analysis of algorithms for the enhancement of educational function in the context of the phenomenon of the Museum as a sociocultural institution, studied extensively by the authors ${ }^{27}$ demonstrates clearly that the "museum-textbook" model gives way to the new "factory of impressions" model, as determined by the influence of the ideas discussed above and the transmodern realities.

The possibilities for creating impressions and images are provided by the introduction of multimedia, which facilitate development of the virtual Museum departments and virtual exhibitions, as well as the influence on personality, due to the augmented reality technology. ${ }^{28}$ An example of effective use of this technology is seen in the State Darwin Museum in Moscow. It "brings to life" the zoological exhibition: the animals step out from show-cases and surround the viewer. Thus, visitors get familiarized with the behavioral patterns of each species, their exterior characteristics and movement patterns in an

\footnotetext{
27 SHLYAKHTINA, Lyudmila M. and Elena N. MASTENITSA. Museum pedagogical conceptions in Russia: historical essays. Saint Petersburg: Saint Petersburg State University of Culture and Arts Publishers, 2006. 271 p.

28 The term "augmented reality" (AR) was introduced in 1990 by Tom Codell and David Miselli.
} 
interactive form. Moreover, the audio accompaniment allows visitors to explore the sounds produced by each individual species. $^{29}$

Thus, multimedia systems and IT equipment feature a wide range of functionality, allowing to visualize the cultural heritage and to complement it with information, thereby implementing the educational and recreational potential of the Museum via the created interactive game content. Innovative technologies aid to the security function by creating digital copies of an object, which makes possible studying all features of the original with all damage excluded. In addition, they provide remote access to the cultural heritage, which largely contributes to solving such pressing social problem as contacts with population groups of limited mobility via remote and mediated interaction.

\section{Some conclusions}

While we do not claim the completeness of the above statements and conclusions, it can be asserted with confidence that the determinism of the Museum's mission reflects the objective factors, which expand both the understanding of the Museum phenomenon and the range of its potential influence on the individual and society as a whole. The sociocultural context characterized by globalization, informatization, and axiological deformations, determines the Museum's response to emerging problems, which implies the need for theoretical reflection and revision of the museum's socio-cultural practices.

The expansion of museum documentation caused by the

29 State Darwin Museum [online]. [cit. 2017-10-11]. Available from www: <http://www. darwinmuseum.ru/projects/separate-exp/ dopolnennaya-real-nost $>$. inclusion of tangible and intangible cultural and natural heritage into the scope of museumification leads to the more comprehensive understanding of the Museum as a cultural form and to speak of the changes in the morphology of the Museum world that emerged with museum-type institutions, economuseums, etc.

Transformation of the meaning and purpose of the Museum is also associated with changes in the society demands and expectations of an individual, thus determining the ways of its interaction with the society. The mission of the contemporary Museum is governed by the fact that it becomes an active social agent that implements the objectives of cultural policy. Its mission also reflects the changing opportunities of the Museum to interpret cultural heritage, to actualize the past and to incorporate it into the contemporary life by addressing the objectives of practical hermeneutics. By responding to the modern global challenges and the needs of the visitor, the Museum formulates its mission relying on collections and technology, thus making a visit to the Museum an unforgettable experience. We can not but agree with the American museologist J. C. Dana who stated that "the only and obvious task of the Museum is to add happiness, wisdom and comfort to all members of the society". ${ }^{30}$ This idea has not yet lost its relevance and should make the backbone of the contemporary Museum's mission, regardless of its size, profile and location. Museums have enough capacity, influence and human resources to play a leading role in the renewal of the world. Today, the museum professionals have every opportunity to channel their

\footnotetext{
30 KOROTKOVA, Anastasia. Art museum as an educational center (USA, early 20th century). Bulletin of Russian State University for the Humanities, 2011, no. 17(79), p. 303.
}

talents and abilities for self-analysis and critical evaluation into the stream of vigorous activity. History teaches us that great social changes do not happen in times of economic stability but instead in times of crisis, ordeal and uncertainty, as in our days. Therefore, the Museum community faces the task of creating new content and formats of social interaction to match the new era, as the old formats are no longer effective.

\section{REFERENCES:}

AGAPOVA, Daria. Culture of participation: millions of dialogues. In SHCHERBAKOV, A. A. Museum as an educational space: game, dialogue, culture of participation. Moscow, 2012. 176 p.

AHMAS, Christina. Museum in the transmodern era. In Museology in the 21st century: problems of learning and teaching. Materials of the International scientific conference, Saint-Petersburg, May 14-16, 2008. Saint Petersburg, 2009.

CHUGUNOVA, Anastasia V. Socio-cultural image of the modern museum: models of architectural implementation. Saint Petersburg, 2012. 22 p. PhD thesis, Culturology.

Dictionary of current museum terms. Museum, 2009, no. 5, p. 55-64.

ICOM Code of ethics for museums. Moscow: ICOM Russia, 2007.

ICOM Russia Charter [Access mode]. [cit. 2017-10-11]. Available from www: $<$ http://www.icom.org.ru/get.asp?id >.

KAULEN, Maria E. Museum or non-museum. Museum, 2010, no. 8, pp. 4-11.

KOROTKOVA, Anastasia. Art museum as an educational center (USA, early 20th century). Bulletin of Russian State University for the Humanities, 2011, no. 17 (79), pp. 303-312.

KUKLINOVA, Irina A. Ecomuseums and the concept of regional cultural identity (Case study of France). In Global cultural space. Proceedings of the International scientific forum, April 12-16, 2005. Saint 
Petersburg: Centre for cultural studies, 2005, pp. 346-348.

KULEMZIN, Anatoly M. Ideological aspects of museology. Bulletin of Kemerovo State University of Culture and Arts, 2012, no. 18 , pp. 27-32.

KUZMIN, E. I. and V. R. FIRSOV (eds.). Cultural policies in Europe: Selection of strategy and milestones: coll. of materials. Moscow: Liberia publishers, 2002. 240 p.

LEBEDEV, Alexey V. Museums of the future: information management. Moscow: Progress-Tradition, 2001. $315 \mathrm{p}$.

LESHCHENKO, Anna. The problem of formation of museological terminology at the international level. Museum, 2009, no. 5 , p. 45.

London walk. Museum of the moving image [online]. [cit. 2017-10-11]. Available from www: <http://weekinlondon.ru/?p>.

MORKOVKIN, Y. V. Development strategy for the cultural institution. Market models of economic activity, case study of Ryazan historical and architectural museum-reserve. Handbook for head staff of the cultural institution, 2004, no. 3 , p. 33.

NAVARRO, Oscar. History and memory in the contemporary museum: a few observations from the point of view of critical museology. Problems of museology, 2010, no. 2, pp. 3-11.

SANDELL, Richard. Social inclusion, the museum and the dynamics of sectoral change. Museum and Society, 2003, vol. 1, no. 1, pp. 45-62.

SAPANZHA, Olga S. The theory of the museum and museality: historiographical overview and historical typology. Monograph. Saint Petersburg: NEE "Express" risograph, 2011. 98 p.

SHUMNAYA, T. G. (ed.). Museums of historical profile. Cultural mission. Moscow, 2008. 174 p.

SOTNIKOVA, Svetlana I. Natural history museum: from scientific factology to formation the bases of ecological culture (historical journey). In Abstracts of the scientific conference, November 25-26, 1997. Moscow, 1997, pp. 20-22.

SHLYAKHTINA, Lyudmila M. and Elena N. MASTENITSA. Museum pedagogical conceptions in Russia: historical essays. Saint Petersburg: Saint Petersburg State University of Culture and Arts Publishers, 2006. 271 p.
State Darwin Museum [online]. [cit. 2017-10-11]. Available from www: <http:// www.darwinmuseum.ru/projects/ separate-exp/dopolnennaya-real-nost $>$.

ŠOLA, Tomislav. Eternity does not live here anymore. A glossary of museum sins. Tula, 2013. 356 p.

YURENEVA, Tamara Y. The museum in world culture: monograph. Moscow: Russian word, 2003. 535 p.

\section{ELENA MASTENITSA}

Kafedra muzeologii i kul'turnogo naslediya,

Sankt-Peterburgskiy gosudarstvennyy

institut kul'tury,

Rossiyskaya Federatsiya

lenamast@yandex.ru

The head of Museology and cultural heritage department of Saint Petersburg State University of Culture, PhD in history, associate professor of Museology and cultural heritage department. Graduated from philological faculty of Saint Petersburg State University, postgraduate study of Research institute of culture of the Ministry of Culture of the Russian Federation and the Russian Academy of Sciences in Moscow. Current scientific interests: museology, the phenomenon of open-air museums, history and modern trends in literary museum development, heritage and cultural studies. Author more than 160 publications. Participated in a number of conferences in Europe and Russia, including Russian Congresses in cultural studies (2006, 2008, 2010). Experienced in organization and holding of conferences and seminars, training programs and advanced training courses in St. Petersburg, other cities and regions of Russia. Scientific adviser of 7 post graduates, who got Ph.D.'s in cultural studies. Member of International Committee for Museology (ICOFOM) of International Council of Museums
(ICOM). The expert of UNESCO/ IFESCCO Pilot Project "Running a Museum - XXI Century:

Thematic Regional Capacitybuilding UNESCO/ICOM Trainings and Expert Meetings for CIS Countries" (2014).

Vedoucí Katedry muzeologie a kulturního dědictví na Státní univerzitě kultury v Petrohradu. Má titul PhD v historii

a je docentkou muzeologie a kulturního dědictví na této katedře. Vystudovala Filologickou fakultu univerzity v Petrohradě a studovala v postgraduálním programu na Výzkumném institutu kultury Ministerstva kultury Ruské federace a Ruské akademie věd v Moskvě. Ve své vědecké praxi se zaměřuje na muzeologii, fenomén skanzenů, historii a moderní trendy ve vývoj muzeí literatury, kulturní dědictví a kulturní studia. Je autorkou vice než 160 publikací. Zúčastnila se řady konferencí v Evropě a Rusku, včetně Ruského kongresu kulturních studií $(2006,2008$, 2010). Organizuje a spolupořádá konference a semináře, studijní programy a pokročilé studijní kurzy v Petrohradě a dalších městech a regionech Ruska. Byla odbornou poradkyní sedmi postgraduálních studentů, kteří získali titul Ph.D v kulturních studiích. Členka Mezinárodního výboru pro muzeologii (ICOFOM) a Mezinárodní rady pro muzea (ICOM). Odbornice pilotního projektu UNESCO/IFESCCO „Jak řídit muzeum - 21. století: Tematické regionální budování kapacity studijních a odborných setkání zemí CIS v rámci UNESCO/ ICOM" (2014).

\section{LYUDMILA SHLYAKHTINA}

Kafedra muzeologii i kul'turnogo naslediya,

Sankt-Peterburgskiy gosudarstvennyy institut kul'tury,

Rossiyskaya Federatsiya

shlyahtinalm@rambler.ru

Honored figure in higher school of Russian Federation, $\mathrm{PhD}$ in 
pedagogics, associate professor of Museology and cultural heritage department of Saint Petersburg State University of Culture. Graduated from historical faculty of Saint Petersburg State University, postgraduate study of St. Petersburg State University of Culture. Repeatedly participated in international symposia, conferences, scientific seminars and as expert in research projects. The developer and leader of seminars to improve the skills of Museum employees held in Russia and the CIS. Author of over 120 publications, including textbooks, monographs, scientific articles.

Current scientific interests:

theoretical problems of museology, museum communication, museum visitor, museum psychology and museum pedagogic. Scientific adviser of 6 post graduates, who got Ph.D.'s in cultural studies. Member of International Committee for Museology (ICOFOM) of International Council of Museums (ICOM). The expert of UNESCO/IFESCCO Pilot Project "Running a Museum XXI Century: Thematic Regional Capacity-building UNESCO/ICOM Trainings and Expert Meetings for CIS Countries" (2014).

Přední odbornice v oblasti kultury a vzdělání v Ruské federaci. Má titul PhD v pedagogice, je docentkou muzeologie a kulturního dědictví na Státní univerzitě kultury v Petrohradu. Vystudovala historii na univerzitě v Petrohradu a studovala v postgraduálním programu Státní univerzity kultury. Opětovně se účastní mezinárodních sympozií, konferencí a vědeckých seminářu a je expertkou výzkumných projektů. Pořádá a vede semináře sloužící ke zlepšení dovedností muzejních pracovníků v Rusku a zemích CIS. Je autorkou více než 120 publikací, včetně učebnic, monografií a vědeckých článků. Ve své vědecké praxi se zaměřuje na teoretické problémy muzeologie, muzejní komunikaci a návštěvníky, psychologii a pedagogiku muzeí. Byla odbornou poradkyní šesti postgraduálních studentů, kteří získali titul Ph.D v kulturních studiích. Členka Mezinárodního výboru pro muzeologii (ICOFOM) a Mezinárodní rady pro muzea (ICOM). Odbornice pilotního projektu UNESCO/IFESCCO „Jak řídit muzeum - 21. století: Tematické regionální budování kapacity studijních a odborných setkání zemí CIS v rámci UNESCO/ ICOM" (2014). 